\title{
Transnational science and collaborative networks. The case of Genetics and Radiobiology in Mexico, 1950-1970
}

\author{
Ana Barahona (*)

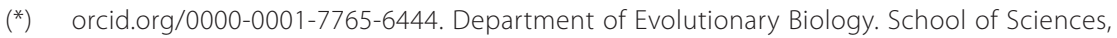 \\ UNAM, Mexico. ana.barahona@ciencias.unam.mx
}

Dynamis

[0211-9536] 2015; 35 (2): 333-358

http://dx.doi.org/10.4321/S0211-95362015000200004
Fecha de recepción: 14 de julio de 2014

Fecha de aceptación: 16 de abril de 2015

SUMMARY: 1.- Introduction. 2.-The creation of the National Commission of Nuclear Energy. 3.- The Genetics and Radiobiology Program. 3.1.-Alfonso León de Garay in an international setting. 3.2.-The foundation of the Programa de Genética y Radiobiología. 3.2.1.—Cytogenetic studies of chromosome abnormalities. 3.2.2.-The study of the effects of radiation on the hereditary material. 3.2.3.-Population Genetics Studies. 4.-Conclusions.

ABSTRACT: The transnational approach of the science and technology studies (S\&TS) abandons the nation as a unit of analysis in order to understand the development of science history. It also abandons Euro-US-centred narratives in order to explain the role of international collaborative networks and the circulation of knowledge, people, artefacts and scientific practices. It is precisely under this perspective that the development of genetics and radiobiology in Mexico shall be analyzed, together with the pioneering work of the Mexican physician-turnedgeneticist Alfonso León de Garay who spent two years in the Galton Laboratory in London under the supervision of Lionel Penrose. Upon his return de Garay funded the Genetics and Radiobiology Program of the National Commission of Nuclear Energy based on local needs and the aim of working beyond geographical limitations to thus facilitate the circulation of knowledge, practices and people. The three main lines of research conducted in the years after its foundation that were in line with international projects while responding to the national context were, first, cytogenetic studies of certain abnormalities, and the cytogenetics and anthropological studies of the Olympic Games held in Mexico in 1968; second, the study of the effects of radiation on hereditary material; and third, the study of population genetics in Drosophila and in Mexican indigenous groups. The program played a key role in reshaping the scientific careers of Mexican geneticists, and in transferring locally sourced research into broader networks. This case shows the importance of international collaborative networks and circulation in the constitution of national scientific elites, and also shows the national and transnational concerns that shaped local practices.

KEY WORDS: Alfonso León de Garay, circulation of knowledge, collaborative networks, genetics and radiobiology program, transnational science. 


\section{Introduction}

The field of science and technology studies (S\&TS) has recently focused on the need to write connected transnational narratives based on a symmetrical treatment of global and local contexts that describe the dynamics of scientific practices $^{1}$. As Subrahmanyam has pointed out, connected histories, as opposed to comparative ones, need to be written to shade light on local resistances and global trends. This transnational approach of S\&TS abandons the nation as a unit of analysis in order to understand the development of science history. It also abandons Euro-US-centred narratives in order to explain the role of international networks and the circulation of knowledge, people, artefacts and scientific practices ${ }^{2}$. This new perspective, according to Turchetti and colleagues «could promote a novel understanding of science as historical phenomenon $»^{3}$.

The transnational approach has been influenced by the effects of globalisation, multiculturalism and the formation of circuits of practices, organizations, objects, goods, knowledge and people, in which scientific developments go beyond nation-state borders, being the collaborative

1. For the notion of «connected histories» Subrahmanyam, Sanjay. Connected histories: notes towards a reconfiguration of early modern Eurasia. Modern Asian Studies. 1997; 31: 735762. For «symmetrical treatment» see Mateos, Gisela; Suárez, Edna. Mexican science during the Cold War: and agenda for physics and the life sciences. Ludus Vitalis. 2012; 20: 47-69, and Suárez, Edna; Barahona, Ana. Postwar and Postrevolution: medical genetics and social anthropology in Mexico (1945-1970). In: Gausemeier, Bern; Müller-Wille, Staffan; Ramsden, Edmund, eds. Human heredity in the twentieth century. London: Pickering \& Chatto; 2013, p. 101-112.

2. Recent historiographical studies have shown the complexity, and in many cases overlap, of the terms «national», «international», or «global» and «transnational». According to Cueto and colleagues, «national» is understood to be that which constrains the nation as a unit; "global» is that which transcends nations, and «transnational» is that which transcends the nation without implying a global scope. Brown, Theodore M.; Cueto, Marcos; Fee, Elizabeth. The World Health Organization and the transition from «international» to «global» public health. American Journal of Public Health. 2006; 96: 62-72.

3. Turchetti, Simone; Herran, Néstor; Boudia, Soraya. Introduction: have we ever been «transnational»? Towards a history of science across and beyond borders. The British Journal for the History of Science. 2012; 45 (3): 319-336 (320). 
networks the units of historical analysis ${ }^{4}$. This new focus pays attention to the flows themselves, and moves away from mere international issues ${ }^{5}$. Thus, recent debates regarding global and local contexts have called attention to circulation networks that explore inter-regional exchanges and transnational circuits that allow quicker cross-border transmission of scientific practices and a faster flow of people, ideas and artefacts ${ }^{6}$.

In the case of historical studies of science in Latin America, a lot of research performed under this approach has indicated that despite their historiographical and epistemological importance, narratives on the national sciences perspective have revealed its analytical limitations. This research has expressed the need to reconstruct transnational stories that account for how the knowledge produced in developing countries forms part of international knowledge as it circulates in international networks of collaboration. This perspective has enabled the production of narratives that go beyond the national framework through analysis of transnational participants and processes, and has permitted new ways of thinking about science history in national and regional contexts. Some of these historians

4. For a critique of «the nation» as a category of analysis in science history, Turchetti; Herrán; Boudia, n. 3; for a more problematized view of national versus international or transnational science, and of «national science» versus «science in a nation», Walker, Mark. The «national» in international and transnational science. The British Journal for the History of Science. 2012; 45 (3): 359-376; here the author argues that seeing science as a «national activity» is not only a recurrent attitude, but also an inevitable one.

5. Pestre, Dominique. Concluding remarks. Debates in transnational and science studies: a defence and illustration of the virtues of intellectual tolerance. The British Journal for the History of Science. 2012; 45 (3): 425-442.

6. Sivasundaram, Sujit. Sciences and the global: on methods, questions, and theory. Isis. 2010; 101: 146-158; Safier, Neil. Global knowledge on the move. Itineraries, Amerindian narratives, and deep histories of science. Isis. 2010; 101: 133-145; Hofmeyr, I. African history and global studies: a view from South Africa. The Journal of African History. 2013; 54: 341-349. Druglitrø, Tone; Kirk, Robert G. W. Bulding transnational bodies: Norway and the international development of laboratory animal science, ca. 1956-1980. Science in Context. 2014; 27 (2): 177-186. See also the special issue New directions and challenges in histories of health, healing and medicine in South Africa. Medical History. 2014; 58 (2); Van der Leuten, E. Towards a transnational history of technology: meanings, promises, pitfalls. Technology and Culture. 2008; 49 (4): 974-994; Birn, Anne-Emanuelle; Necochea López, Raúl. Footprints on the future: looking forward to the history of health and medicine in Latin America in the twenty-first century. Hispanic American Historical Review. 2011; 91: 503-527. 
have insisted on more transnational and global histories that take into account the dynamics of scientific practices ${ }^{7}$.

In this work, the term «transnational» allows us to understand the formation of the Genetics and Radiobiology Program (Programa de Genética y Radibiología, PGR) of the National Commission of Nuclear Energy (Comisión Nacional de Energía Nuclear, CNEN), based on local needs and the aim of working beyond geographical limitations to thus facilitate the circulation of knowledge, practices and people from the USA and England to Mexico and from Mexico to the said countries. The idea of circulation is introduced in this essay to elaborate on the journeys involved in knowledge production, in practices that are in search of reproduction and verification ${ }^{8}$. In this case study, the term allows us to study the paths through which genetics and radiobiology were introduced to and constructed national scientific policies in Mexico, and

«[... to reflect on the details of the travels, to pose and eventually answer questions regarding how knowledge and practices travel through geographical spaces and through time. The movements, shifts and travels are not taken

7. Here are just a few of these many works. Marcos Cueto, M. Cold war, deadly fevers: malaria eradication in Mexico, 1955-1975. Washington, DC: Woodrow Wilson Center, Washington/ Baltimore: Johns Hopkins University Press; 2007; Hurtado de Mendoza, Diego; Vara, Ana María. Winding roads to Big Science: experimental physics in Argentina and Brazil. Science, Technology and Society. 2007; 12: 27-48; McCook, Stuart. The world was my garden: tropical botany and cosmopolitanism in American science, 1898-1935. In: McCoy, Alfred W.; Scarano, Francisco A., eds. Colonial crucible: Empire in the making of the modern American state. Madison: University of Wisconsin Press; 2009, p. 499-507; Hochman, Gilberto, G. Priority, invisibility and eradication: the history of smallpox and the Brazilian public health agenda. Medical History. 2009; 53: 229-252; Soto Laveaga, Gabriela. Jungle laboratories; Mexican peasants, national projects, and the making of the pill. Durham: Duke University Press; 2009; Medina, Eden. Cybernetic revolutionaries: technology and politics in Allende's Chile. Cambridge: The MIT Press; 2011; Mathews, Andrew S. Instituting Science. Authority, expertise, and power in Mexican forests. Cambridge: MIT Press, 2011; Escobar, Arturo. Encountering development: the making and unmaking of the Third World. Princeton: Princeton University Press; 2012; Podgorny, Irina. Fossil dealers, the practices of comparative anatomy and British diplomacy in Latin America, 1820-1840. The British Journal for the History of Science. 2013; 46 (2): 647674; McCook, Stuart. Introduction. Isis. 2013; 104 (4): 773-776; Horta Duarte, Regina. Between the national and the universal: natural history networks in Latin America in the Nineteenth and Twentieth Centuries. Isis. 2013; 104 (4): 777-787.

8. Santesmases, María Jesús; Gradmann, Christoph. Circulation of antibiotics: an introduction. Dynamis. 2011; 31 (2): 293-302. 
for granted, but rather are included in the account as an agent: circulation is itself history» ${ }^{9}$.

It is precisely under this perspective that the creation of the PGR of the CNEN in the 1960s in Mexico shall be analyzed, together with the pioneering work of the Mexican physician-turned-geneticist Alfonso León de Garay. In this work, the idea of circulation allows us to understand in greater detail how it is that knowledge and scientific practices have travelled across geographical and temporal spaces, crossing nations and passing through borders. In this text, I shall attempt to show how the PGR was created from a simultaneous dialog between the local context responding to national needs and concerns, and a transnational approach owing to its need for international networks through which scientific resources were mobilized in order to enter into a transnational material culture. From the start, de Garay was as committed to the construction of shared languages and practices as he was to networks of collaboration in order to guarantee the necessary conditions for establishing genetics in Mexico. This study also allows us to place Mexican science within a global context in which connected narratives describe the interplay between global trends and national contexts.

I will present my historical analysis in two parts. In the first, I will talk about the creation of the CNEN within local and international contexts, in order to observe its influence on the foundation of the PGR. In the second, I will show how the training of Alfonso León de Garay at the Galton Laboratory of University College in London was crucial to the establishment of the PGR. I will also show how his subsequent membership of international networks facilitated the flow of knowledge and the circulation of scientific practices and people, which included the training of young geneticists in foreign academic institutions, thus enabling spaces to be opened for the development of genetics in Mexico. This historical reconstruction will show the relations between different actors in different countries and at different times, and the scientific programs and institutions that were created in the 1950 s and 1960s.

9. Santesmases, María Jesús. Circulating knowledge and practices in the atomic age. Radioisotopes in Spain, 1945-1955. In: International Colloquium Peaceful Atoms: Science during the Cold War. Mexico City; 2012. 


\section{The creation of the National Commission of Nuclear Energy}

In the early 1950s, an acceleration in the arms race and atomic tests became apparent as a result of the bombings of Hiroshima and Nagasaki that put an end to the WWII. Within this international context, President Dwight D. Eisenhower gave the Atoms for Peace speech on December 8th 1953 before the UN General Assembly in which he stated his preference for halting the military and war-faring uses of nuclear energy and offering peaceful nuclear technology to humanity instead ${ }^{10}$. Eisenhower suggested the creation of an international organization to regulate the process for creation and use of atomic energy and proposed that countries with nuclear technology projects contribute economical and technical resources to the development of peaceful uses of nuclear energy. Later on, one of the resolutions passed during the 1955 International Conference on the Peaceful Uses of Atomic Energy held in Geneva, Switzerland, was the creation of the International Atomic Energy Agency (IAEA), which would come into being in October of 1957 at its headquarters in Vienna ${ }^{11}$. The member countries of the UN were invited to participate by creating their own national institutions to attend relevant meetings and benefit from the knowledge produced and establish control mechanisms. Several of these organisms were created before or concurrently with the formalization of the IAEA in 1957, as was the case for the $\mathrm{CNEN}^{12}$. The creation of the IAEA increased funding sources for

10. Eisenhower, Dwight D. Atomic Power for Peace. In: Pilat, Joseph F. Atoms for Peace. A Future after fifty years? Washington, DC: Woodrow Wilson Center Press; 2007, p. 239-246. As Creager and Santesmases have shown, «even before President Eisenhower's initiative, biology, agriculture, and medicine served to represent the peaceful face of atomic energy», but it was only after WWII that medical practices and biological knowledge changed drastically. Creager, Angela; Santesmases, María Jesús. Radiobiology in the Atomic Age: changing research practices and politics in comparative perspective. Journal of the History of Biology. 2006; 39: 637-647 (640).

11. Fischer, David. History of the International Atomic Energy Agency. The first forty years. Vienna: IAEA; 1997. Among the Mexican delegation that attended the Conference were Manuel Sandoval Vallarta, Nabor Carrillo and Carlos Graef. We will see the connection with the PGR below.

12. For example: EURATOM was founded within the European Economic Community in 1957, the European Agency for Nuclear Energy (AEEN) as part of the OECD in 1957, and the European Organization of Nuclear Research (CERN) as part of UNESCO. Rigalt, Antonio R. Los principios y las instituciones relativas al derecho de la energía nuclear. La política nuclear. México: Universidad Nacional Autónoma de México; 1988. 
nuclear scientists and technicians with emphasis on the peaceful uses of radioisotopes in medical genetics and agriculture, among others ${ }^{13}$.

The interest of Mexican scientists and politicians did not begin with the creation of the CNEN. According to Vélez Ocón, Mexican nuclearity ${ }^{14}$ began as a result of the atomic bombings in Japan, when the Mexican government declared nuclear deposits of uranium, thorium and actinium, national reserves in $1945^{15}$. At the end of 1945, General Ávila Camacho's government lobbied enthusiastically for the attendance of a Mexican representative at the atomic tests the US would hold. This was how Harvard-educated Guggenheim Fellow soil engineer Nabor Carrillo, who was at the time the Scientific Research Coordinator at the UNAM and Soil Mechanics Research Section Head of the Commission for Promotion and Coordination of Scientific Research (Comisión Impulsora y Coordinadora de la Investigación Científica, CICIC), was invited to attend the Bikini Atoll tests as an observer in 1946, along with Colonel Juan Loyo González. Most countries, Mexico included, declared themselves in favor of the peaceful use of atomic energy, and stated that the atomic bomb and other weapons of destruction would bring permanent peace to the world ${ }^{16}$. At a national

13. For example, in 1963 the IAEA worked on a program for nuclear disalting. One year later, then-President Lyndon B. Johnson launched the «Water for Peace Program», as part of the so-called «agro-industrial complex» for using the nuclear power for desalting sea water; in this way the fresh water could be used to irrigate crops and at the same time the reactor's heat could be used to generate electricity. Chile, Greece, Mexico, Peru, Taiwan, Tunisia and Turkey asked the IAEA for advice. The US and Mexico planned to build a plant in the Gulf of California for these purposes, but never came into being due to the high economic costs. Fischer, n. 11, p. 156-158.

14. Mateos; Suárez, n. 1. They develop this concept after Hetch's. Hecht proposed the term «nuclearity» to mean «the degree to which a nation, a program, a policy, a technology, or even a material counted as "nuclear"». Hecht, Gabrielle. Negotiating global nuclearities: apartheid, decolonization, and the Cold War in the making of the IAEA. Osiris. 2006; 21: 25-48 (25).

15. Vélez Ocón, Carlos. Cincuenta años de energía nuclear en México 1945-1995. México: Programa Universitario de Energía, UNAM; 1997.

16. For science and technology as tools of international diplomacy Beatty, John. Genetics in the atomic age: the atomic bomb casualty commission, 1947-1956. In: Benson, Keith R.; Maienschein, Jane; Rainger, Ronald, eds. The expansion of American biology. New Brunswick: Rutgers University Press; 1991, p. 284-324; Krige, John. Atoms for Peace, scientific internationalism, and scientific intelligence. Osiris. 2006; 21: 161-181. For political instruments, Creager, Angela. Radioisotopes as political instruments, 1946-1953. Dynamis. 2009; 29: 219-239. For México, Domínguez Martínez, Raúl. Historia de la Física Nuclear en México. 1933-1963. México: UNAM/ Centro de Estudios sobre la Unviersidad/Plaza y Valdés Editores; 2000, p. 97. 
level, President Ávila Camacho had founded the CICIC in 1942. Its first director, even while he was living in the US, was Dr. Manuel Sandoval Vallarta, the Mexican MIT-educated Guggenheim Fellow physicist. He had collaborated with MIT from 1923 to 1946, and traveled to Mexico several times to promote nuclear energy studies. In about 1943, the CICIC established the first radioactivity research laboratory, which had been promoted by Sandoval Vallarta with the main objective of developing radiochemistry. This was because one of his chief scientific concerns was acid rain. The head of the soils mechanics laboratory at the time was his colleague and friend, Nabor Carrillo ${ }^{17}$.

From this moment on, interest in the study of atomic energy grew in Mexico, and so the nuclear research program was set up. Dr. Carrillo, who was Rector of the UNAM at the time, visited the American company High Voltage Engineering Corporation in Cambridge, Massachusetts, thanks to Dr. William Buechner's invitation to attend the facilities and familiarize himself with the equipment. This allowed the UNAM to install a Van de Graaff accelerator with federal support in the $1950 \mathrm{~s}^{18}$. The immediate effect of this was, on the one hand, the development of research, including the commencement of various projects and the training of technicians on radioisotope techniques, and on the other, an increase in and consolidation of institutional relationships and collaborations between Mexican and foreign scientists. Chief among these collaborations was that of Mexican Harvardeducated and Guggenheim Fellow physicist Dr. Carlos Graef - Sandoval's former student-, who was interested in cosmic radiation and relativity, with Harlow Shapley, the high-profile promoter of the US National Academy of Sciences and director of the Harvard College Observatory.

The creation of the CNEN was endorsed in a bill presented by the Executive Branch to the House of Representatives of the 42nd Legislature on October 25th 1955, although the project dated back to $1954^{19}$. The approval granted by the House of Representatives in November of the same year highlighted the efficiency of nuclear energy as an energy source, besides

17. Bulbulian, Silvia; Rivero Espejel, Ignacio A. Historia de la radioactividad en el Instituto de Investigaciones Nucleares. Boletín de la Sociedad Química de México. 2012; 6 (1): 15-26.

18. Domínguez Martínez, Raúl. Los orígenes de la física nuclear en México. Revista CTS. 2012; 21 (7): 95-112.

19. Archivo del Instituto Nacional de Investigaciones Nucleares, AC-ININ, s/C, folio 000008, Iniciativa de Ley que crea la Comisión Nacional de Energía Nuclear, 25 Oct 1955, p. 28. 
considering it a more economical source than oil, coal or hydropower. This bill was sent to the Senate for approval in December 1955, was finally published in the Official Gazette on December 31st 1955 and the CNEN came into being on January 1st 1956 as a body of the Federal Executive Branch, with its own legal status, assets and legal standing for achieving its objectives ${ }^{20}$. The materials that were included in the act were uranium, thorium and all elements from which energy could be obtained by means of nuclear reactions in significant quantities. On June 1st 1956, President Adolfo Ruiz Cortines appointed the lawyer and ex-President of the Supreme Court José María Ortiz Tirado as chairman of the Commission, and Doctor Nabor Carrillo and Doctor Manuel Sandoval Vallarta as members. The Advisory Board would be comprised of Doctors Alberto Barajas Celis, Fernando Alba Andrade and Carlos Graef Fernández, José Mireles Malpica (M.Sc.) and the engineers Eduardo Díaz Losada and Jorge Suárez Díaz.

The CNEN was founded upon two general fields of interest: energy and non-energy applications, and nuclear science studies. It was created with a complement of nine programs: nuclear physics, education and training, seminars, reactors, radioisotopes, industrial afflictions from radiation, agronomy, genetics and radiological protection. Thanks to the efforts of Sandoval Vallarta, Nabor Carrillo and Carlos Graef, who prompted the study of nuclear physics in Mexico, land and resources were obtained to develop a nuclear center. In 1964, construction began on the «Nabor Carrillo» Nuclear Center as part of the CNEN in the town of Salazar, State of Mexico, and both a Triga Mark III reactor and a Tandem Van de Graaff positive ion accelerator were acquired. These facilities would house all the CNEN's programs and laboratories that were scattered throughout the city, and give support to other institutions such as the UNAM and the National Polytechnic Institute (Instituto Politécnico Nacional, IPN) ${ }^{21}$ (figures 1 and 2).

20. Since its inception, the Mexican nuclear program has had civilian and not military purposes, so the word «atomic» was excluded because of its implications for war and the arms race. Instead, the word «nuclear» was included, due to its peaceful connotations - energy and non-energy applications, as well as studies in nuclear science that included agronomy and genetics among others. Vélez Ocón, n. 15.

21. The CNEN would later become the National Nuclear Energy Institute (Instituto Nacional de Energía Nuclear, INEN) in 1972, and the National Nuclear Research Institute (Instituto Nacional de Investigaciones Nucleares, ININ) in 1979. Domínguez Martínez, n. 18, and Barahona, Ana; Pinar, Susana; Ayala, Francisco J. La Genética en México. Institucionalización de una disciplina. México: Coordinación de Humanidades, UNAM; 2003. 


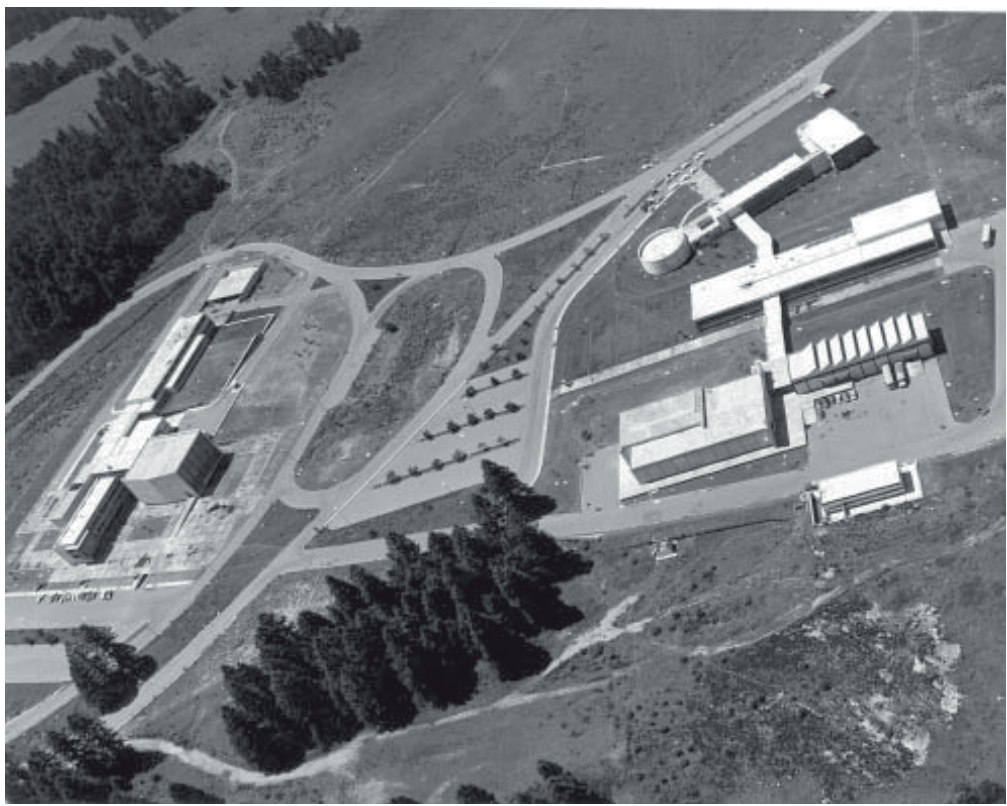

Figure 1. Aerial view of the Nuclear Center in Salazar, circa 1965. Courtesy of the National Nuclear Energy Institute.

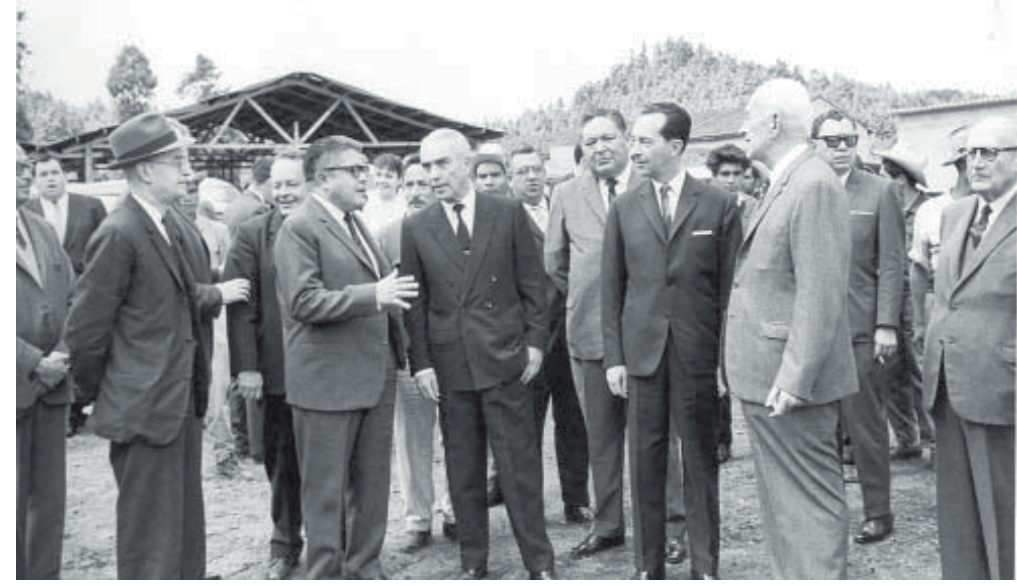

Figure 2. From left to right Manuel Sandoval Vallarta, Carlos Graef Fernández (behind), Nabor Carrillo, Juan Fernández Albarrán, Antonio Ortiz Mena (on behalf of the Mexican President Adolfo López Mateos), and José María Ortiz Tirado, during the ceremony to lay the foundation stone of the Nuclear Center in the town of Salazar. 1964. Courtesy of the National Nuclear Energy Institute. 
It is through the CNEN that nuclear physics and genetics and radiobiology were connected in Mexico with the foundation of the PGR, opening new contexts for the development of genetics and radiobiology. As we will see, to advance his own interests, de Garay took advantage of the opportunities for peaceful uses of nuclear energy afforded by national and international institutions founded after WWII ${ }^{22}$.

\section{The Genetics and Radiobiology Program}

\subsection{Alfonso León de Garay in an international setting}

After having spent two years in the Galton Laboratory at University College London, under the supervision of British medical geneticist Lionel Penrose, the Mexican physician Alfonso León de Garay founded the PGR under the CNEN. As we shall see, de Garay was part of an international network in human genetics in which the circulation of researchers, knowledge and practices enabled the assimilation and modification of genetic practices in Mexico in the early 1960s. It was in these years, when global trends in human genetics were reshaping the field of biomedicine in the aftermath of WWII, and when growing international interest in understanding the effects of radiation on human beings led to the formation of institutions and a proliferation of multi-centered clinical trials and inter-laboratory studies ${ }^{23}$.

Alfonso León de Garay (1920-2002) studied medicine in the 1940s at the Autonomous University of Puebla, and served for many years as a neurologist. In 1957, he decided to study population genetics with Penrose, the Head of the Galton Laboratory ${ }^{24}$. Thanks to an agreement between

22. For a comparative study on what effects the foundation of national atomic energy facilities had on radiobiology, Creager; Santesmases, n. 10; Creager, Angela. Life Atomic. Chicago: The University of Chicago Press; 2013.

23. Cambrosio, Alberto; Keating, Peter; Bourret, Pascale. Objetividad regulatoria y sistemas de pruebas en medicina: el caso de la cancerología. Convergencia. 2006; 13 (42): 135-152; Barahona, Ana. Medical genetics in Mexico. The origins of cytogenetics and the health care system. Historial Studies in the Natural Sciences. 2015; 45 (1): 147-173.

24. de Garay, Alfonso León. Interview with author; August 1998. 
the IAEA and some European universities, de Garay obtained a grant and went to London ${ }^{25}$.

After WWII, the Galton Laboratory was considered the cradle of human genetics and one of the most prestigious academic institutions in population genetics. With Penrose as Head, and other colleagues such as John B. S. Haldane, Harry Harris, Hans Kalmus, Julia Bell, and Ursula Mittwoch, several aspects of human genetics were being tackled, and some of the most up-to-date techniques were being standardized. For example, Harris focused on the newly developed paper chromatography and gel electrophoresis techniques to measure genetic variability, Hans Kalmus was working on the genetic disorder of color blindness, and Ursula Mittwoch on sex determination and differentiation. This laboratory played a pivotal role in the development of human genetics worldwide ${ }^{26}$. During the years that de Garay lived in England, he met distinguished personalities and the human and population genetics elite of those times. The relationships he established in Europe were extremely influential on the PGR he founded upon his return to Mexico in 1960, and had a profound and lasting importance in his later career and on his thinking.

When de Garay was in England, he attended the 1957 general assembly of the IAEA as a companion to the English representatives, and there he met the Mexican delegation composed of José María Ortiz Tirado, Nabor Carrillo and Manuel Sandoval Vallarta, and the Secretary General of the CNEN, Mr. Salvador Carmona. They urged him to complete his studies and return to Mexico in order to found a program where he could begin studies into the effects of radiation on health.

As a result of this meeting, and due to the support of the Mexican delegation, de Garay went on to study the mutagenic effect of radiation, in line with projects that were being developed in other parts of the world. In 1957, with the support of both Ortiz Tirado and Dr. Alexander Hollaender, head of the Division of Biology at the Oak Ridge National Laboratory of

25. In the years after WWII, international collaborations were also used as tools for policy intervention of the US in other countries through, for example, grant programs. In Mexico, this argument is useful because it shows how the support of the IAEA through the CNEN allowed de Garay to travel abroad and return to open up spaces for new generations of geneticists, which resulted in the departure of many other young researchers in order to specialize. Miller, Clark A. An effective instrument of peace: scientific cooperation as an instrument of US foreign policy, 1938-1950. Osiris. 2006; 21: 133-160.

26. Harper, Peter S. A short history of medical genetics. Oxford: Oxford University Press; 2008. 
the US Atomic Energy Commission, de Garay was able to go to Oak Ridge and become well-grounded in the field of radiobiology 27 .

In concert with his goal of establishing radiobiology as a major field of research in Mexico, he further enhanced his own background in 1958 by attending an International Course on Radioisotope Techniques at the Centro de la Oficina Sanitaria Panamericana in Puerto Rico. During this period, he also attended several courses on radiobiological protection, radioisotope techniques, and autoradiography offered by the Atomic Research Institute at Harwell, England ${ }^{28}$. His return to Mexico was hastened because the CNEN insisted on the immediate set-up of a laboratory, due to international pressures that Mexico should develop its own research in genetics and radiobiology. At the time, de Garay was well positioned and able to take advantage of the international call for the peaceful uses of nuclear energy.

\subsection{The foundation of the Programa de Genética y Radiobiología}

The PGR started its planning phase in 1957, after de Garay had met the commissioners of the CNEN in Vienna. The Program was established in 1960 in order to

«[...] contribute to the conservation of health, physical and mental improvement, and sickness prevention, through the investigation of the factors which intervene (favorably or unfavorably) in the biological inheritance of the population ${ }^{29}$.

De Garay's agenda was two-fold. On the one hand, he intended to open up spaces for the development of genetics and radiobiology in Mexico, and on the other, to promote the PGR on the international stage. This interplay

27. As a consequence of the Atoms for Peace program, the Oak Ridge Laboratory offered courses on radioisotope techniques to foreing scientists. Among the first Mexican scientists to attend was the chemist Augusto Moreno y Moreno in 1954. From 1958 he offered courses on radioisotope techniques at the UNAM, and from 1960 in close collaboration with de Garay and the CNEN. For experimental radiobiology at Oak Ridge, see Rader, Karen, A. Alexander Hollaender's postwar vision for Biology. Journal of the History of Biology. 2006; 39: 685-706.

28. Villalobos-Pietrini, Rafael; Guzmán, Judith; Levine, Louis. Homenaje a Alfonso León de Garay. Revista Internacional de Contaminación Ambiental. 2005; 21: 5-8.

29. De Garay, Alfonso León. Programa de Genética y Radiobiología. Informe de Labores 1960. México: Comisión Nacional de Energía Nuclear, Archivo de Información, Biblioteca del ININ. 1960. 
between de Garay, the PGR, the CNEN and the IAEA fostered the circulation of ideas and practices beyond transnational borders. To achieve this agenda, de Garay's objectives were the study of the effects of radiation on human health, and the study of diverse specific aspects of the heredity process, from the molecular level up to population genetics.

The PGR consisted at first of a small staff composed of six researchers, including de Garay as director, Rodolfo Félix Estrada, chief of the Drosophila section, and María Cristina Cortina Durán, María Teresa Zenzes Eisembach, Víctor Manuel Salceda Sacanelles, and Claudina Berlanga Siller, who obtained their B.A. degrees in biology in 1960, as well as a technician, a secretary, and a service assistant. By the end of the 1960s, the number of sections increased to include, for example, human genetics and molecular genetics sections $^{30}$ (figure 3 ).

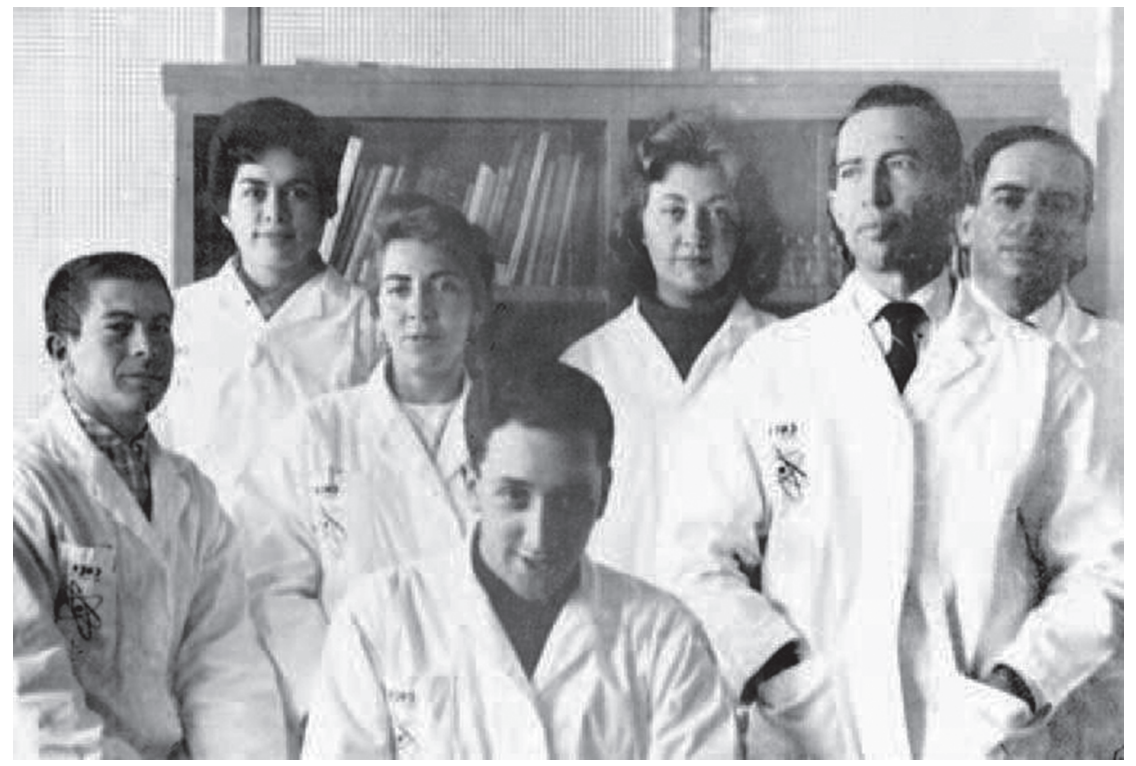

Figure 3. From left to right: Víctor Salceda Sacanelles, María Cristina Cortina Durán, María Teresa Zenzes Eisembach, Ubaldo Rodarte, Claudina Berlanga Siller, Alfonso León de Garay and Rodolfo Félix, circa 1965. Courtesy of Alfonso León de Garay.

30. De Garay, Alfonso León. Programa de Genética y Radiobiología. Informe de Labores 1960-1970. México: Comisión Nacional de Energía Nuclear, Archivo de Información, Biblioteca del ININ. 1970. Barahona; Pinar; Ayala, n. 21. 
The facilities were located in a 249 square meters apartment in Mexico City divided in two parts. One part was the laboratory for genetic research with ionizing radiations; the other was dedicated to the tissue cultures and research on the fruit fly Drosophila, plus a darkroom and an office for the secretary. The Program consisted of six sections: tissue culture (where cytology and genetic analysis were practiced), photography (microphotography and autoradiography), biochemistry (biochemistry and radiochemistry), education (preparation of educational materials and training of personnel), Drosophila labs (conventional experimentation and computing of mutations, including irradiated stocks), and statistics and social work (population genetics and family studies).

The three main lines of research conducted in the years after its foundation that were in line with international projects while responding to the national context were, first, cytogenetic studies of certain abnormalities; second, the study of the effects of radiation on hereditary material; and third, the study of population genetics in Drosophila and in Mexican indigenous groups.

\subsubsection{Cytogenetic studies of chromosome abnormalities}

The 1960s was a decade of intensive work in the area of human genetics; it was transformed into an enticing frontier for medical research, and the production of technological knowledge from the study of chromosomes held a great deal of hope for progress in the study of human heredity. The technical analysis of the karyotypes and practices that accompanied it became popular worldwide as it allowed human chromosomes to be analyzed and visualized ${ }^{31}$.

31. For a historical study on the techniques developed at the time to study human chromosomes, de Chadarevian, Soraya. Putting human genetics on a solid basis: human chromosome research, 1950-1970. In: Gausemeier; Müller-Wille; Ramsden, n. 1, p. 141-152; Santesmases, María Jesús. Size and the centromere: translocations and visual cultures in early human genetics. In: von Schwerin Alexander; Campos, Luis, eds. Making mutations: objects, practices, contexts. Berlin: Max Planck Institut für Wissenschaftsgeschichte; 2010, p. 189-207; Santesmases, María Jesús. Cereals, chromosomes and colchicine: crop varieties and human cytogenetics at the Estación Experimental Aula Dei, 1948-1958. In: Gausemaier; Müller-Wille; Ramsden, n. 1, p. 127-140; Santesmases, María Jesús. The autonomous karyotype and the origins of prenatal testing: Children, pregnant women and early Down syndrome cytogenetics, Madrid 1962-1975. Studies in History and Philosophy of Biological and Biomedical Sciences. 2014; 47 (Part A): 
De Garay had come into contact with these techniques in England. Upon his return, he brought the first human chromosome preparations that have been studied in the Galton laboratory and donated by Penrose. These studies also led to the standardization of laboratory tissue culture methods, and in general, those practices enabling visualization of chromosomes. To do so, the PGR was assisted by Dr. David A. Hungerford, the American scientist and co-discoverer of the chromosomal abnormalities in cancer cells who worked at the Institute for Cancer Research in Philadelphia. He came to Mexico in 1963 to work on the protocols for the tissue culture from peripheral blood technique that he and his colleagues had developed in the US, which was originally designed for the study of chromosomes in patients with cancer and in laboratory animals with radiation-induced leukemia ${ }^{32}$. As a result of this collaboration, Hungerford agreed to receive in Philadelphia, PGR technicians Tayde García and Pilar Quijano to specialize in tissue culture and other cytological techniques that had been standardized at Hungerford's laboratory, who upon their return were incorporated to the cytogenetic section of the PGR.

Therefore, the cytological studies included congenital malformations and chromosomal alterations due to radiation, concurrently with what was happening in other laboratories around the world. Chromosomal illnesses in human beings, such as Down syndrome and Turner syndrome, were analyzed along with other illnesses due to translocation and nondisjunction (figure 4).

As part of his personal agenda and in response to national needs, de Garay encouraged young people to learn cytogenetic techniques that were being standardized in other laboratories, always with the support of the IAEA through the CNEN ${ }^{33}$. The first to go abroad were María Cristina Cortinas de Nava from 1962 to 1965 at the Hôpital des Enfants Malades to learn techniques of human cytogenetics (certain cytogenetic studies appearing at this time were related to leukemia), in collaboration with the French

142-153. Another research group was being formed in the 1960s at the Mexican Institute of Social Security. Barahona, Ana. Historia de la genética humana en México, 1870-1970. Mexico: UNAM; 2009; Barahona, n. 23.

32. de Garay, n. 30.

33. As a State member of the IAEA, the PGR received direct economical aid from the International Technical Assistance Program of the IAEA. As being part of the CNEN, the PGR's budget was approved for federal agencies, for this reason de Garay stated that «the minimal expenditures for our research have been scrutinized carefully». De Garay, n. 30, p. 81. 


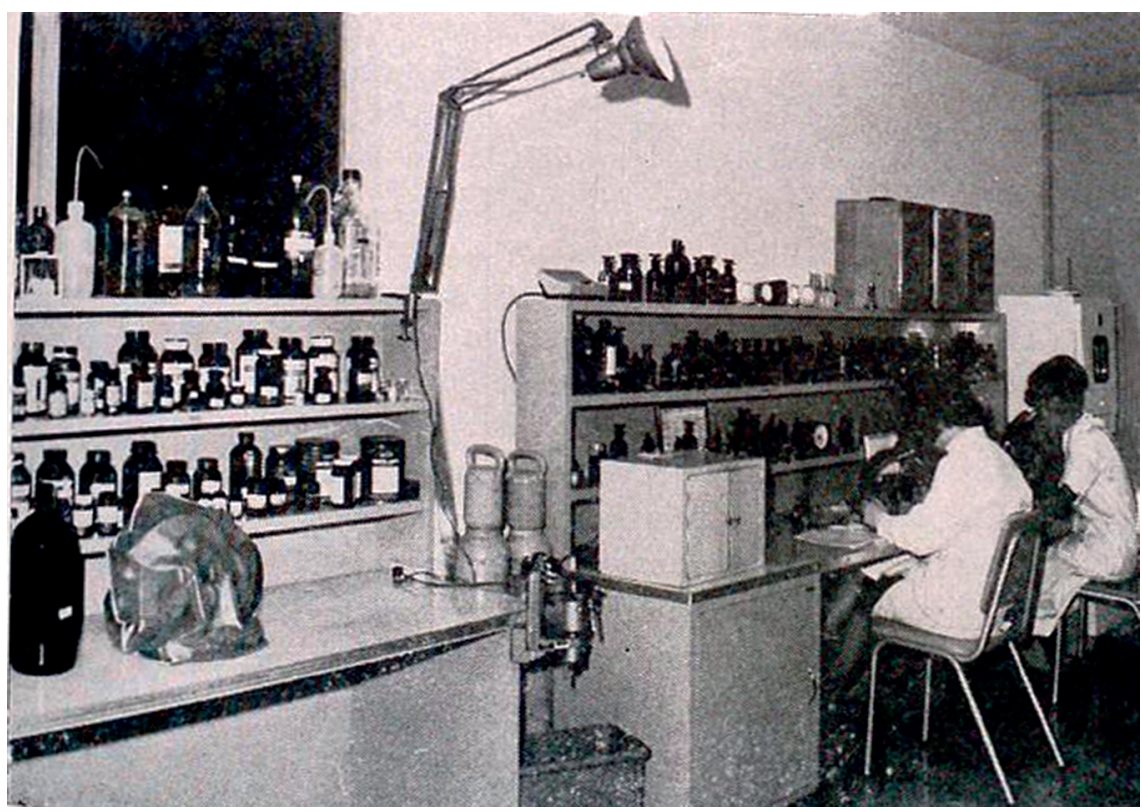

Figure 4. Partial view of the Cytogenetics laboratory. Courtesy of the National Nuclear Energy Institute.

geneticist Jean de Grouchy's group in France ${ }^{34}$; and María Teresa Zenses Eisenbach from 1963 to 1964 at Texas University to work with Chinese geneticist T. C. Hsu (his main research focused on comparative and cancer cytogenetics) on techniques for human and animal cytogenetics. The CNEN also provided scholarships for students to complete their undergraduate studies. The first to obtain a scholarship was Olga Olvera who joined the cytogenetics projects ${ }^{35}$.

As the PGR expanded, new projects were developed, such as genetic and anthropological studies of Olympic athletes. In terms of influence beyond Mexico, this project was very important as a site of transnational collaboration. The 1968 games were to be held in Mexico City, so de Garay

34. De Grouchy, Jean; Cortinas de Nava, Cristina; Bilski-Pasquier, G. Duplication d'un Ph1 et suggestion d'une evolution clonale dans une leucémie myéloïde chronique en transformation aiguë. Nouvelle revue française d'hématologie. 1965; 5: 69.

35. Barahona; Pinar; Ayala, n. 21. Years later, Olvera went to Walter Plaut's laboratory at the University of Wisconsin-Madison, to study radiographic techniques applied to genetics. 
used his scientific and political contacts with the CNEN to send a letter to local Olympic Organizing Committee President, Pedro Ramírez Vázquez, on November 15th, 1966. Ramírez Vázquez, along with José Gorostiza (then President of the CNEN), approved the creation of the Genetics and Human Biology Program (GHBP) the same year, and commissioned de Garay to lead the project ${ }^{36}$. By March 31st 1967, the head of the GHBP Rodolfo Félix, a close collaborator of de Garay, sent Eduardo Hay, the General Director of the Mexican Olympic Centre, the general project of the program, mentioning that it had been prepared in close collaboration between the CNEN and the Mexican Olympic Organizing Committee. Eduardo Hay would then arrange for a site to accommodate the program's different laboratories to be used at the Olympic Centre in the south of Mexico City which was called the Olympic Village (Villa Olímpica) ${ }^{37}$. He also provided the necessary space and equipment to conduct genetics and anthropology sampling protocols on Olympic athletes.

Its planning phase began working on the protocols in $1967^{38}$. Thus, the First International Seminar for the Study of Olympic Athletes was held in Mexico City from June 17th to 21st, 1967. Mexican participants in the seminar included Alfonso León de Garay, Rodolfo Félix Estrada, Santiago Genovés, Felipe Montemayor, Alejo Romero and Virginia Tiburcio. Louis Levine, Douglas Bainbridge, Jehanna Faulhaber, Barbara H. Heath, Hans Kalmus, Ching Chun Li, Eugene Schenider and Curt Stent from several different countries formed the international contingent. The results of this first seminar were recommendations for conducting the study (which included points of view from the geneticists, anthropologists, biochemists and physicians who participated in the discussion), and for the standardization of techniques and apparatus. Another two seminars followed, which were held prior to the games in 1968, and in 1969 to analyze all the data collected ${ }^{39}$.

The main objective of the GHBP was to study the genetic and somatic components which determine an Olympic athlete's abilities. This investigation

36. Letter from Alfonso León de Garay to Pedro Ramírez Vázquez. General National Archive (Arhivo General de la Nación, AGN), Genetics and Human Biology Program, box 757, exp. 41.

37. Letter from Rodolfo Félix to Eduardo Hay. AGN, Genetics and Human Biology Program, box 757, exp. 41.

38. The first time that cytogenetic techniques were applied to sports context was in the 1966 European Championship in Budapest, this being a good time for the PGR to be included in an international sporting network. de Chadarevian, n. 31.

39. AGN, Genetics and Human Biology Program, box 757, exp. 41. 
included 1,265 games participants and covered family studies, cytological investigations, research on single genes and analysis of finger and palm prints ${ }^{40}$. These studies were carried out by independent teams, working in close collaboration with each other; for example, the karyotyping technique used was that of Barbara Honyman Heath and Lindsay Carter, both of whom carried out most of the work along with Johanna Faulhaber and Mexican PGR geneticists Olga Olvera and Rosario Rodríguez Arnaiz. Another team headed by physician Alejo Romero studied the distribution of blood groups; PGR technicians María Teresa García and Virgina Tiburcio carried out the study on genetic markers associated with enzymatic factors and sensitivity to phenylthiocarbamide. Other PGRs personnel participated with Ursula Mittwoch of the Galton Laboratory in the sex determination of the athletes using sexual chromatin and buccal smear tests ${ }^{41}$. According to de Garay, this program was completely funded by the Olympic Organizing Committee and represented a great effort for the development of science in Mexico as well as positioning it within an international setting.

\subsubsection{The study of the effects of radiation on the hereditary material}

After WWII, the international call from institutions such as the IAEA, to study the effects of radiation on humans, led to the establishment of local programs, such as the PGR, where de Garay introduced the study on the effects of radiation in the hereditary material. According to de Garay, the increasing uses of nuclear energy in electricity production and medical applications, agriculture and industry, forced him «to increase research and concentrate scientific, technical and legal efforts intended to prevent any damage that may arise from nuclear development» ${ }^{42}$. After that, new

40. De Garay, n. 30, p. 99. The results of the study were published in: de Garay, Alfonso León; Levine, Lous; Carter, Lindsay, J. E. Genetic and anthropological studies of olympic athletes. New York: New York Academic Press; 1974. The GHBP invited 4,168 athletes out of 6,084 who attended the games. $20.8 \%(1,265)$ of the athletes actually went to take the genetic and anthropological tests.

41. Olvera, Olga. Importancia del Laboratorio de Genética y Radiobiología de la Comisión Nacional de Energía Nuclear. Contacto Nuclear. México: Instituto de Investigaciones Nucleares. 2001; 22: 16-23.

42. De Garay, Alfonso L. Programa de Genética y Radiobiología. Informe 1962. México: Comisión Nacional de Energía Nuclear. Archivo de Información. Biblioteca del ININ; 1962, p. 2. 
prospects for the peaceful application of nuclear energy and research in general opened up gradually within the PGR.

While serving as director of the Program, de Garay continued to expand his background in the field, so he atended an International Course on Advanced Radioisotope Techniques from 1961-62 at the Radioisotope Training Center of the Weizmann Institute in Rehovot, Israel. A few years later, he attended a course on Medical Genetics in 1966 at the American College of Physicians at Johns Hopkins Hospital in Baltimore ${ }^{43}$. These trips allowed him to expand his collaborative network and to strengthen the studies performed in the PGR.

The Drosophila section studied the mutagenic effects of diverse radiation-emitting sources by using tracer isotopes. As part of the staff training, annual courses about radioisotopes and nuclear instrumentation were organized in order to obtain and analyze these mutants. These were offered in the Radioisotope Laboratory at the Physics Department of the School of Sciences of the UNAM in close collaboration with the CNEN, by himself and Augusto Moreno y Moreno, whom he had met at the IAEA meeting in Vienna in 1957. The first course was held from March-July in $1960^{44}$. These courses works were compulsory for the personnel who worked in the Program ${ }^{45}$. By 1962 de Garay and collaborators had obtained 57 Drosophila mutants that were used for research and educational purposes (figure 5).

In the ensuing years, and to be competitive on a worldwide scale, the PGR included the Aquatic Invertebrate Radiobiology section and the Molecular Genetics Laboratory in 1965 and 1966. The idea was to work, respectively, on protective compounds against radiation effects in the flatworm Planaria, and to investigate the genetic mechanisms operating in microorganisms, as well as the radiation effects and consequences of

43. From 1969-70, he served as a member of the group of experts at the UN that was established to examine the effects of the acquisition, proliferation, possession, and development of nuclear weapons. He also served as an advisor to the Mexican Delegation at the meetings of the UN Scientific Committee on the Efects of Radiation (UNSCEAR) and was designated Expert ad personam by the UN General Secretary U. Thant. From 1971-72 he was the Alternate Representative to the IAEA and the UN Organization for Industrial Development. VillalobosPietrini; Guzmán; Levine, n. 28.

44. See n. 27.

45. Olvera, Olga; Guzmán, Judith. Interview with author, Laboratorio de Genética, ININ. September 12, 2001. 


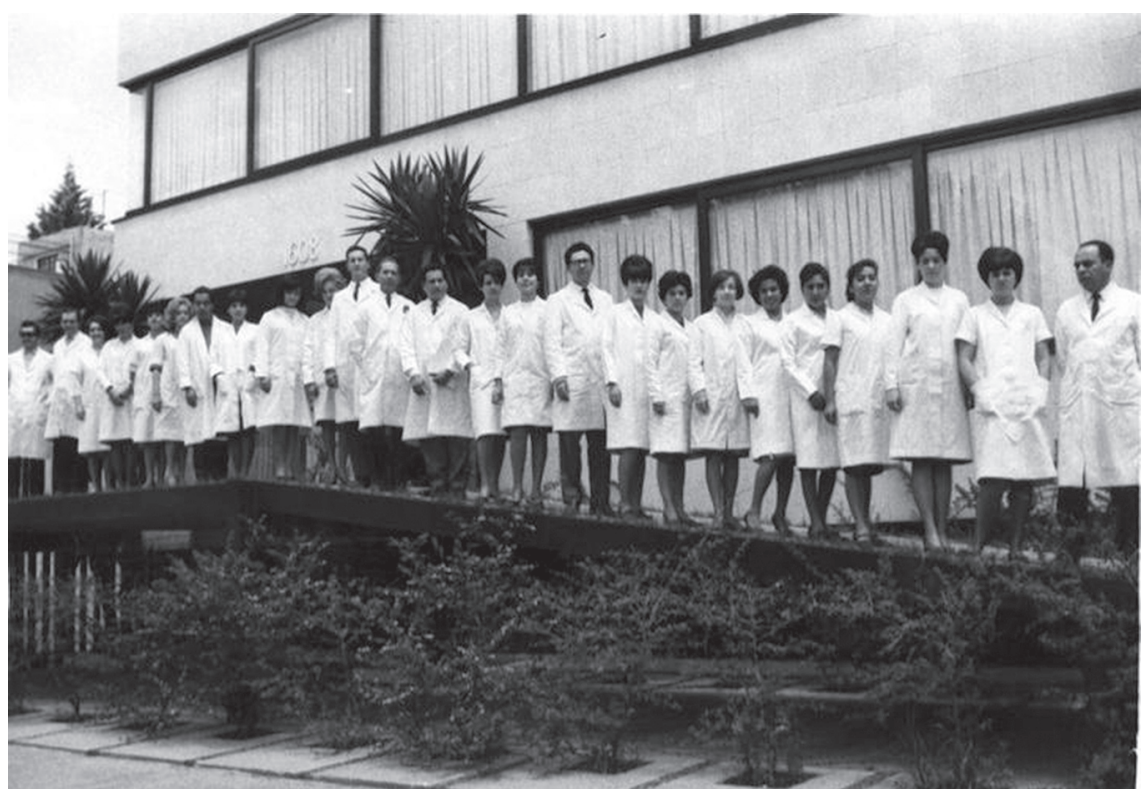

Figure 5. Alfonso León de Garay (bellow the second palm tree from left to right) and his students ca. 1966. Courtesy of the Manuel Sandoval Vallarta Archive, UAM.

radioprotective substances at the molecular level. In parallel, de Garay encouraged Magadalena Carrillo Santín to go to the Atomic Energy Institute at Sao Paulo, Brazil, to study radiochemistry in 1965, and he invited the then-Director of the Oak Ridge National Laboratory of the US, Alexander Hollaender, whom he had met in 1957 at Oak Ridge, to see the facilities and to work on future collaborations in 1966. Unfortunately, and due to the PGRs involvement in the 1968 Olympic Games, this collaboration did not continue. With this policy, the PGR warranted its membership of the international networks in which ideas, practices and resources were being mobilized.

\subsubsection{Population Genetics Studies}

Although population genetics had been developed in the first decades of the 20th Century, it was in the post-war years that serological studies of the 
distribution of blood groups were developed with the intention of measuring the intra-specific variability in human populations. This was possible thanks to the introduction of new techniques such as gel electrophoresis and paper chromatography, which were quickly built to track immune reactions, mainly thanks to the work of Harry Harris at the Galton Laboratory (and whom de Garay had met in England) with human isoenzymes.

In Mexico, human population studies started in the 1940s with the work of physician Mario Salazar Mallén and his students at the General Hospital on the detection of hemoglobin abnormalities in rural communities. Between 1944 and 1949 he published several papers on the blood agglutinogens of the Mexicans, and blood type surveys of urban and indigenous populations ${ }^{46}$. This work was followed by Adolfo Karl at the National Polytechnic Institute, who studied the distribution of abnormal hemoglobin in a Mazatecan group of the Papaloapan basin using the horizontal electrophoresis technique ${ }^{47}$. At that time, the Mexican populations were investigated for ethnographic, anthropological or economic purposes, but rarely from the genetic point of view, so these studies were important in the Mexican local context.

These studies, although aligned with the work of other laboratories in other parts of the world, did not impact Mexican genetics, until other groups such as those of de Garay and Mexican physician Rubén Lisker began to use molecular tracers and more up-to-date electrophoresis techniques to measure the genetic variability of Mexican indigenous populations ${ }^{48}$.

To start these kinds of investigations at the PGR, de Garay invited the physician and biologist Hans Kalmus, the prewar refugee from Czechoslovakia, whom he had met in the Galton Laboratory, to design the study of population genetics of Drosophila and Mexican indigenous populations.

Kalmus' first visit thanks to the support of the IAEA was in 1962, but only for a three-month period; these visits became more common and longer in the ensuing years. Under his supervision, gathering expeditions

46. Salazar Mallén, Mario. El aglutinógeno Lewis en la sangre de los mexicanos. Boletín del Instituto Médico Biológico. 1949; 7: 25-30; Salazar Mallén, Mario; Hernández de la Portilla, Raúl. Existencia del aglutinógeno Rh en los hematíes de 250 individuos Mexicanos. Revista de la Sociedad Mexicana de Historia Natural. 1944; 5: 183-185. See also Barahona, n. 31.

47. Karl, Adolfo. Estudio electroforético de la hemoglobina de los indígenas mazatecos de la cuenca del Papaloapan. Ciencia. 1957; 17: 85-86. See also Barahona, n. 31.

48. In 1960, another research group headed by Lisker at the Nutrition Diseases Hospital (later the Salvador Zubirán National Institute of Nutrition) was working on the genetic characterization of Mexican indigenous populations. Barahona, n. 31. 
were made to Chiapas and Oaxaca to collect data on Drosophila. Similarly, thanks to this collaboration they began the study of population genetics in indigenous populations using tracer genes of Tzeltal and Tzotzil groups in Chiapas and Mixtec groups near the coast of Oaxaca. Later on, the Lacandon populations in Chiapas and the Otomí group in Hidalgo were investigated. The results of these studies showed that in some communities, the frequencies of certain genetic characteristics increased by prolonged isolation in a small geographical area ${ }^{49}$ (figure 6).

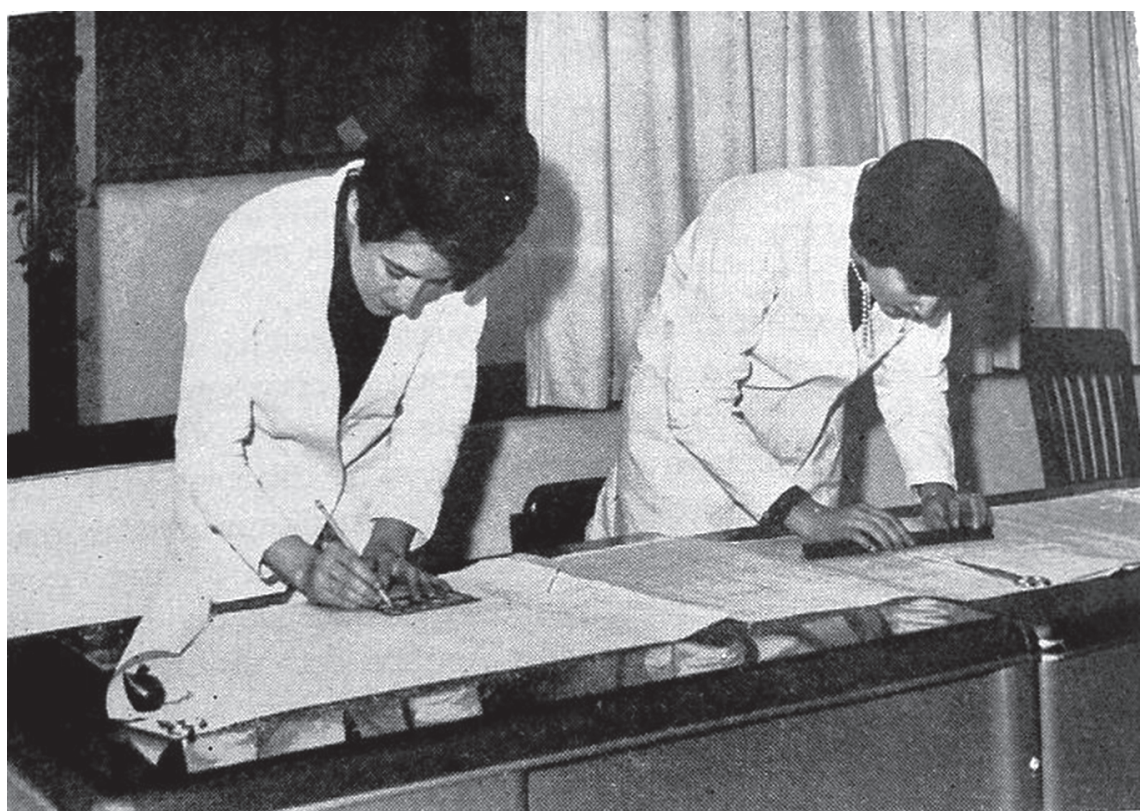

Figure 6. Human Genetics section. Technicians are analysing the pedigrees of the Lacandon populations. Courtesy of the National Nuclear Energy Institute.

Finger and palm prints were also taken, and tests were performed for phenylthiocarbamide tasting, enzyme deficiencies in the school population,

49. Barahona, n. 31; de Garay, Alfonso L. Programa de Genética y Radiobiología. Informe de Labores 1963. México: Comisión Nacional de Energía Nuclear, Archivo de Información. Biblioteca del ININ; 1963. 
color blindness and the chemical composition of earwax ${ }^{50}$. In order to obtain blood samples and analyze them later in the laboratory, several gathering expeditions were necessary owing to the geographical conditions of the regions studied and the intervention of other Mexican institutions such as the National Indigenist Institute and the Summer Institute of Linguistics.

Owing to the growth of the program, de Garay requested a greater budget from the CNEN authorities. Thus the PGR moved to another building in the south of Mexico City whith a surface area of 560 square meters where other projects could be carried out and more staff could be hired.

In order to strengthen this line of research, de Garay arranged for Víctor Salceda to be a visiting scholar at the Rockefeller University in New York, at the laboratory of the Russian-born American geneticist and evolutionist Theodosius Dobzhansky to study genetic load in irradiated populations. This occurred from 1965 to 1967, and enabled the PGR to collaborate with Dobzhansky, who visited Mexico in 1974 at the invitation of de Garay.

The IAEA provided Salceda with a scholarship to go to New York, and he joined Dobzhansky's laboratory in November 1965 to do research on the genetic load of irradiated Drosophila flies. When Salceda went back to Mexico in 1967, he tried to initiate collections of D. pseudoobscura in natural populations under Dobzhansky's advice, in order to study the geographical distribution of the chromosomal inversions that characterize this species. Because of Dobzhansky's illness and because de Garay's group was involved in the organization of the Olympic Games held in Mexico in 1968, this project did not take off at the time ${ }^{51}$.

The context and the conditions in which this research was performed, the commencement of international collaborations, and the role of de Garay and his group in the circulation of knowledge were key pieces in the

50. Kalmus, Hans; de Garay, Alfonso L.; Rodarte, Ubaldo; Cobo, Luis. The frequency of PTC tasting, hard ear wax, color blindness and other genetical characters in urban and rural Mexican populations. Human Biology. 1964; 36: 134.

51. Dobzhansky went to Mexico years later, in 1974, to initiate the project entitled «Population Genetics of Mexican Drosophila». The Mexican participants were Rodolfo Félix, Judith Guzmán, María Esther de la Rosa and Victor Salceda, the US participants were Louis Levine and Jeffrey R. Powell. Barahona, Ana; Ayala, Francisco J. The role played by Theodosius Dobzhansky in the emergence and institutionalization of genetics in Mexico. Genetics. 2005; 170: 981-987; Barahona, Ana; Ayala, Francisco J. History of genetics in Mexico. Nature Review / Genetics. 2005; 6 (11): 860-866. 
development and establishment of genetics in Mexico and its positioning at an international level.

\section{Conclusions}

The creation of the CNEN in Mexico played an essential role in the foundation of the PGR in the 1960s. Mexican physicians conveyed and consolidated the emerging model of human genetics in research during these years in Mexico. These scientists assimilated knowledge and techniques learned outside Mexico and applied them to domestic needs. Thus, medical elites and local scientists were able to join international networks, despite the unequal nature of their relationship with scientists from other parts of the world. The case in question aimed to show precisely how academic studies, interaction and collaboration with Mexican and foreign scientists, and the formation of specialized teams, allowed de Garay and his group to enter the field of human genetics. The members of the PGR were important pieces in the movement of knowledge across borders due to their standing as experts, which was possible thanks to the moral and epistemic authority they had acquired by studying abroad, and through their personal relationships.

The analysis of scientific networks that de Garay belonged to indicates the authority that this conferred upon him at a local level to further his interests and pursue his personal agenda. It also allowed him to promote his ideas outside of local geographical boundaries whether by means of sponsors such as the IAEA through the CNEN or by consolidating international standards. The networks of collaboration that de Garay belonged to were the facilitators and depositories of locally produced knowledge within Mexican material culture that made possible scientific exchanges and the standardization of genetic practices. As stated by Turchetti and colleagues, «the establishment of these networks confers the authority needed to strengthen sourced scientific ideas and propel them beyond borders by means of either patronage, or wider circulation, or adherence to international standards» ${ }^{52}$. The PGR worked productively to balance the frictions of local needs to produce new forms of knowledge for attacking national problems such as the study of Mexican indigenous populations, and transnational

52. Turchetti; Herran; Boudia, n. 3, p. 331. 
trends, as shown by the lines of cytogenetics and radiobiology, to mobilize material resources in continuous dialog with other genetic centers and laboratories in the world.

Between 1960 and 1970, more than 25 people were trained abroad with the support of the IAEA and the CNEN, and more than 20 scholars from different laboratories around the world were invited to participate in the PGR's activities. The knowledge and diverse practices learned on these trips taken by both researchers to Mexico and students abroad, enabled the development of projects, the standardization of techniques and the publication of results in international journals in the 1960s. This turned the PGR into one of the leading programs in Mexico, whose academic production placed it on the world stage. The PGR's growth was not casebased, far from it, it was adapted to the field's development abroad, because for De Garay current scientific advances determined the basic guidelines to follow in a dialog with local needs. The PGR played a key role in reshaping the scientific careers of Mexican geneticists, and in transferring locally sourced research into broader networks. This case shows the importance of circulation in the constitution of national scientific elites, and also shows the national and transnational concerns that shaped local practices.

\section{Acknowledgments}

I would like to thank M.C. Alicia Villela González for expert research assistance; to Carlos Cervantes, Nuria Gutiérrez and Marco Ornelas for their help during this investigation; to David Bevis for his careful copyediting, and two anonymous reviewers for their valuable comments on a previous version of this paper. Many of these ideas were discussed with Soraya de Chadarevian, Angela Creager, John Krige, María Jesús Santesmases, Edna Suárez and Karin Zachmann during the session on Transnational Science During the Cold War at the ISHPSSB meeting in Montpellier, France in July 2013. 